\title{
Personal Financial Management Behaviors during the Covid-19 Pandemic: Evidence from Vietnam.
}

\author{
Le Thanh Tam*, Nguyen Thi Ha Trang, Ngo Thi Ngoc Anh, Ngo Thi Thu Mai \\ National Economics University, Ha Noi, Viet Nam \\ Corresponding author: tamlt@neu.edu.vn
}

Received: 31, March, 2021

Accepted: 07, April, 2021

Published: 11, April 2021

\begin{abstract}
This paper is aimed at investigating the factors affecting personal financial management behaviors in Vietnam during the Covid-19 pandemic. With data of interviewing online 477 individuals, the research team used the reliability test with Cronbach's Alpha, exploratory factor analysis (EFA), Pearson correlation analysis's results, and linear OLS model. The key findings are: First, four factors have strong impacts on personal financial management behavior are: (i) Covid-19 pandemic; (ii) Financial habits from parents; (iii) Financial education from parents; (iv) Financial well-being. Of which, the factor of socialization has been separated in to "financial habits from parents", and "financial education from parents". Second, differently from previous studies, two variables of financial knowledge and financial attitude have no impact on personal financial management behavior. These differences come from the special characteristics of Vietnam culture: First, parents are the main financial sources for the youth, and also the model of financial management for children. Second, as financial management capacity building courses are not much available in Vietnam, people depend on family own's experiences to build up their financial management behaviors. Basing on the results, the recommendations are focusing on improving financial management capability of parents in order to improve individual financial management capacity.
\end{abstract}

Keywords: Covid-19 pandemic, financial education, financial management behavior, financial well-being, financial habit.

JEL classification: G21, G40, G50, I22.

\section{Introduction}

Financial management behavior plays a very important role, directly affects the financial situation of individuals. Bad financial management behavior or low knowledge of financial management could lead to unforeseen consequences such as: being into personal credit default and having difficulties in life. In particular, when the Covid-19 pandemic is still going on, personal financial management skills should be improved.

However, nowadays, the percentage of Vietnamese adults with understanding of financial management has been only quite low at 24\% (Global Financial Literacy Excellence Center, 2015). Furthermore, those people who lose their jobs or deal with wage cuts without even having any proper financial management plan including making provisions and saving for future, they could turn out to be the most vulnerable group (The Global Risks Report, 2021), but in Vietnam, there few studies addressing the issue comprehensively, most authors just focus on knowledge finance, or spending management, and money savings which are just secondary factors of personal financial management behavior. Therefore, this study is carried out to cover all financial management behavior aspects of individuals in Vietnam.

\section{Literature review}

\subsection{Personal financial management behavior}

Kholilah \& Iramani (2013), financial management behavior is the individual's ability to perform key roles (planning, control, search and storage) in the long and short term. Besides, the correctness of the aforementioned opinion on financial behavior has been demonstrated in two previous studies (Parrotta, 1998; Sina \& Noya, 2012). Personal financial management behavior can be described as a learning process in making plans and improving these plans implementation (Parrotta, 1998). According to Sina \& Noya (2012), one of the attempts to shape the personality of financial behavior is developing personal financial management behavior by implementing financial planning and money autonomy. Inheriting the viewpoint of Xiao \& Dew (2011), Mien $\&$ Thao (2015) gave a definition of personal financial management behavior related to cash flow management, investment planning, savings and credit.

2.2. Factors influencing on personal financial management behavior

Based on research model and testing result of relevant previous researches: Hilgert et al (2003), Joo \& Grable (2004), Shim et al (2009), Xiao et al (2009), Ida \& Dwinta (2010), Xiao \& Dew (2011), Woodyard \& Robb (2012), Mien \& Thao (2015), Yab et al (2016), Arifin (2017), Ameliawati \& Setiyani (2018), Van et al (2020), we propose five factors affecting Vietnam's personal 
financial management behavior in the context of the Covid-19 pandemic as follows:

\subsubsection{Financial knowledge}

Financial knowledge can be understood in a variety of definitions, which depends on the perceptions of each individual as well as researcher. According to OECD (2014), financial knowledge is the ability to make wise decisions related to the use and management of money. Arifin (2017) shows the positive effect of financial knowledge on financial behavior, the deeper financial knowledge individuals have, the better they manage finance. Meanwhile, the study of Herdjiono \& Damanik (2016) had the opposite results with the studies outlined above: since financial knowledge education has little effect on countries and regions with low income, in these areas, financial knowledge has no impact on individual financial management behavior.

\subsubsection{Financial attitude}

Financial attitude has an important role in determining the success or failure of someone's financial behavior. In addition, according to Borden et al (2008), financial attitude is a way of thinking and evaluating finance. Ameliawati \& Setiyani (2018) demonstrated the positive impact of financial attitude on personal financial management behavior through analyzing result of the level of financial attitude influencing on management behavior which is 0.522 . The reasonableness of this study is also proven when it coincides with social behavior theory and the results of three reports: Amanah et al (2016), Mien \& Thao (2015), Herdjiono \& Darmanik (2016). However, Anthony et al (2011) stated that financial attitude has a negative relationship with managerial behavior finance.

\subsubsection{Financial well-being}

Financial well-being is defined as happiness and worry-free status about finance and is often based on a subjective assessment of one's own financial situation (Joo, 2008). Joo and Grable (2004) pointed out that financial well-being is related directly and indirectly to financial behaviors. People who are satisfied with financial well-being are considered to have better behaviors such as paying credit cards, maintaining personal budget for future savings than those who are not. Kim et al (2003) illustrated that poor financial management has a negative impact on financial well-being as when financial well-being is not satisfied, survey respondents would make adjustments in financial management to meet your financial desire.

\subsubsection{Financial socialization}

Financial socialization is defined as the process by which each individual gains the values, standards, skills, knowledge and attitudes needed to be a wisely consumer (Beatty \& Capella, 2006). Parents' financial communication with their children has been shown to be positively associated with budgeting, saving, investing, planning, managing cash and credit of children (Jorgensen et al, 2017). Shim et al (2010) also explicated a link between parents' financial guidance and children's credit management behavior. Besides, among determinants which are the education from schools, part-time job experience, parental teaching is the most influential factor to personal financial management behavior.

\subsubsection{The Covid-19 pandemic}

The pandemic of acute pneumonia Covid-19 has caused negative effects on the global economy and Vietnam as well. Thus each individual Vietnamese's finances are impossible to avoid the effect by this pandemic, so every person will have differences in the spending management before and during the pandemic. In the research paper "Assessing the impact of the Covid-19 on spending, saving and investment behavior in Vietnam" by Dinh Thi Thanh Van and her research team of University of Economics - Hanoi National University (2020) concluded that the Covid-19 pandemic has affected all spending, saving and investment behaviors of all age groups, occupations, and gender. These authors shown that those with higher education tend to reduce spending, investing and increase savings compared to the group with lower education. In particular, $63.4 \%$ of respondents of interview tend to cut down the investing transaction number because of their belief in the decline of investment return. In Experian's study (2020) surveyed a group of 377 adults in the United States to find out how their personal financial behavior changed when the pandemic hit the United States. Two-thirds $(66 \%)$ of those surveyed said that they spent equal or less than previous moment when Covid-19 did not occur.

\section{Research Methodology}

\subsection{Data}

Secondary data are collected from desk review to understand the overall picture of Covid-19 Pandemic on Personal Financial Management Behaviors in Vietnam. The primary data is collected online via semi-structured questionnaire to 500 individuals currently residing in Vietnam with random sampling method, of which 477 are verified. The observed variables were measured on a 5-point Likert scale, defined from 1 (completely disagree) to 5 (completely agree). Questionnaires and variables are developed basing on the theories of reasoned action (TRA).

\subsection{Research hypotheses and models}

The 5 determinants of personal financial management behaviors are summarized, with the hypotheses as followed:

Figure 1: Hypotheses of the model

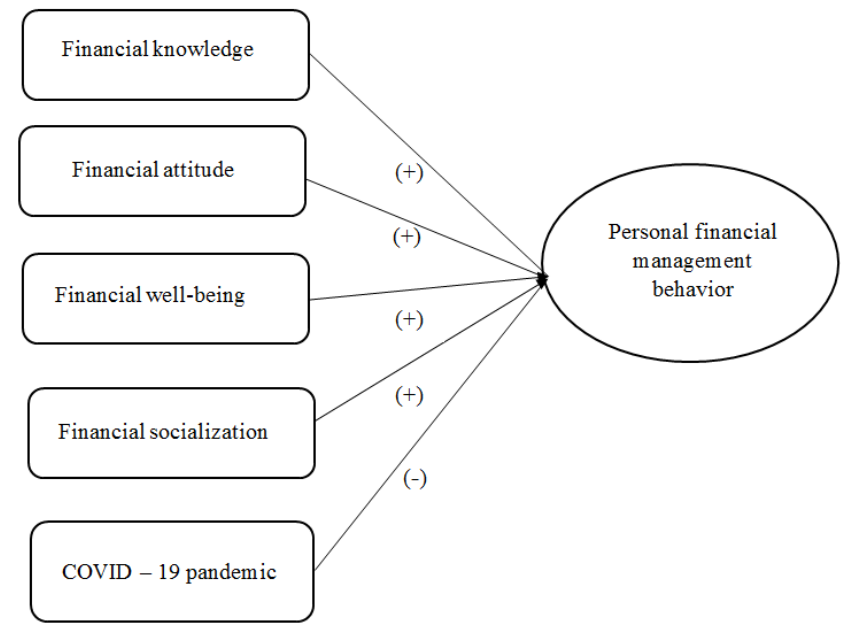

Source: Authors' development based on literature review (2021)

The research team carry out different tests for confirming the statistical significance of the model:

- Test the reliability of the scale: In this study, the research team used Cronbach's Alpha coefficients and explored 
EFA factor analysis to determine the components of each factor, and the main factors affecting personal financial management behavior.

Assess the impact of variable independent to dependent variable: linear regression model

Test the difference in the average value of an entire population: Evaluate through independent

t-Test analysis and One-Way ANOVA.

\subsection{Effects of the Covid-19 pandemic on personal spending}

The first phase of the Covid-19 outbreak in Vietnam, particularly in the second quarter of 2020, under the government's direction of social distance, trading restriction, residents' spending needs significantly reduced. Nonetheless in the later period, from the third quarter of 2020, individuals are inclined to increase spending, buying more, and stimulating consumption demand on account of the policy which is providing emergency assistance.

\section{Personal Financial Management Behaviors in Vietnam in the context of Covid-19}

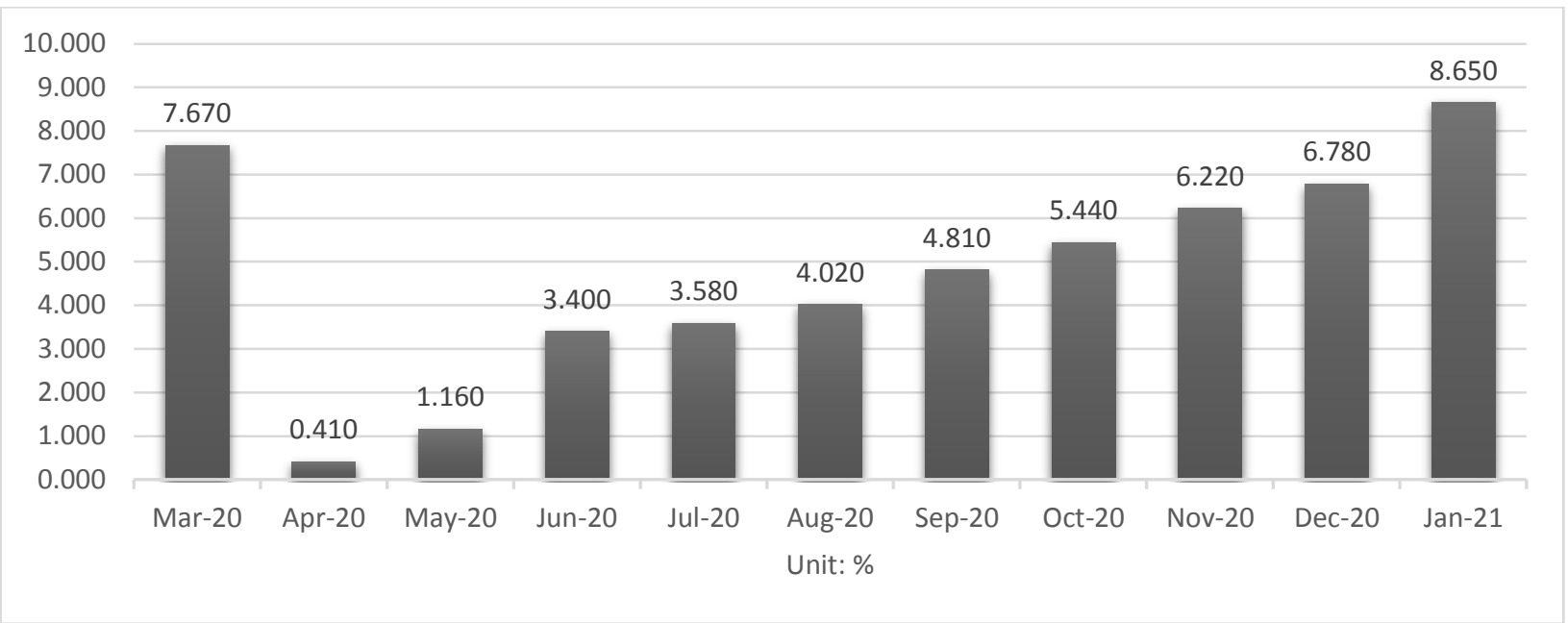

Source: CEIC (2021)

Right after the outbreak of Covid-19 in Vietnam at the end of March, people spent much less in April $(0.401 \%$ of spending increase). However, as Covid-19 pandemic was quite well control under in Vietnam, people started to feel confident and be back to "new normal" with increasing spending over next months from May. The retail shopping situation has gradually improved, especially by the end of 2020 , reached up to $6.78 \%$ and $8.65 \%$ for the first month of the year 2021.

The Covid-19 pandemic has created a significant shift changing purchasing habits from traditional pattern to modern one which applies technology, e-commerce platforms in shopping. Evidence in the report of First Insight (2020), people tend to reduce shopping frequency at physical stores, instead they prioritize buying online. About $30 \%$ of interviewees made online transactions regularly and $39 \%$ cut costs at physical stores. Along with that, payment has also been replaced into non-cash payment.

\subsection{The impact of the Covid-19 pandemic on personal savings}

According to a study by Hanoi National University (2020), only $39.8 \%$ of surveyed people have the same amount of savings after Covid-19, however, $51.57 \%$ had the amount of savings reducing from $10 \%$ - to over $20 \%$ as individuals longed for holding more cash. However, Covid-19 also had a positive impact on people's perception of the importance of saving when the percentage of people knowing the role of saving increased by $13 \%$.

\subsection{The impact of the Covid-19 pandemic on personal credit}

Under the influence of the pandemic, individuals' credit psychology was changed drastically. The Covid-19 pandemic caused the slowdown of the business, the people did not have tendency to borrow money for investment plans, so it can be seen that in the first quarters of 2020, the credit status was not positive. According to the financial statements of Vietinbank and Vietcombank, the amount of loan at the beginning of the first quarter of 2020 at Vietinbank witnessed a decrease in 11785 billion VND, Vietcombank noticed a slight upward trend from 724 290 billion VND to 739956 billion VND. In addition, even though other banks such as VP Bank, VIB Bank, MB Bank, and Kien Long Bank are all banks with a high proportion of personal credit, these banks' personal credit grew only $2 \%$, which proved that personal credit trend was affected more by Covid-19 ( Fiingroup, 2020).

However, on account of the policy which is interest rate reduction, people feel more secure in borrowing money. Therefore, the credit balance of the whole system increased by $7.39 \%$ compared to the end of 2019, which means increasing $1.3 \%$ more compared to the end of September 2020 (Credit Department for Economic Sectors (State Bank), November 18, 2020). Though personal credit's state has recovered, overall, this credit growth has been slow.

\subsection{The impact of the Covid-19 pandemic on personal financial investment}

A report from Hanoi National University (2020) pointed that Covid-19 has a negative impact on the amount of individuals' regular investment capital, with $63.4 \%$ of respondents believed that investment return would decline. Investors under 35 years of age were suffered by Covid-19 more negatively than other age groups as regarding investment activities, the group of people over 35 years old with better economic potential will have better resilience to the Covid-19 pandemic. In terms of profitable portfolio, securities are considered to be the most favored 
investment field during this challenging period, since the number of new trading accounts opened by domestic individual investors only in three months (March, April and May) up to 102427 units.

\section{Research results}

\subsection{Descriptive Statistics of the Samples}

Out of a total of 477 respondents, female accounts for $73 \%$, while that of men accounts for only $27 \%$. More than half of those surveyed have the incomes less than 3 million VND per month (55\%), and $34.4 \%$ of them has the income from 3 to 10 million VND per month. The remaining has the income above 10 million VND per month.

\subsection{Reliability Test with Cronbach's Alpha}

A variable is considered reliable if the value of cronbach's alpha is greater than 0.60 .

In the research, an acceptable Cronbach alpha value of 0.779 was calculated

for the financial knowledge. In which, Cronbach's Alpha coefficient if KT3 deleted $=0.810>0.779$. The research team decided to remove the variable KT3 from the scale.

The financial attitude factor was tested three times Cronbach's Alpha to eliminate invalid observed variables. Because the factor Cronbach's Alpha coefficient three times the factor of Financial attitude is only $0.554<0.6$, the research team decided this scale.

The instrument has been reliable with the cronbach's alpha value of each variable of financial socialization, Covid 19 pandemic, financial well-being, financial management behavior individuals below 0.7 and value of correlation of the observed variables are above 0.3 . These variables can all be used in further analysis.

Table 1: Cronbach ' Alpha coefficient results of the variables in the model

\begin{tabular}{|l|l|l|}
\hline Constructs & Items & $\begin{array}{l}\text { Cronbach's } \\
\text { alpha }\end{array}$ \\
\hline Financial knowledge & KT & 0.810 \\
\hline Financial socialization & XHH & 0.809 \\
\hline Financial well-being & SK & 0.726 \\
\hline Covid 19 pandemic & CV & 0.706 \\
\hline $\begin{array}{l}\text { Personal financial management } \\
\text { behavior }\end{array}$ & H_V & 0.832 \\
\cline { 1 - 3 } & &
\end{tabular}

Source: Authors' compilation result (2021)

\subsection{Exploratory Factor Analysis (EFA) result}

The suitability of the data for EFA was assessed by calculating the Kaiser-Meyer-Olkin (KMO) and Bartlett's test of sphericity. $\mathrm{KMO}$ value was 0.844 and Bartlett's test was significant (sig. = .000 ), supporting the factorability of the correlation matrix. Since the extracted factors were expected to be correlated, an oblique rotation strategy was used to interpret the factors (Sass \& Schmitt, 2010). Total variance extracted values of the independent variables is $68.803 \%$ ( $>50 \%$ ) indicated model fit with EFA test.

Table 2: Results of KMO and Barlett's Test of the independent variables

\begin{tabular}{|l|l|}
\hline KMO and Bartlett's Test \\
\hline $\begin{array}{l}\text { Kaiser-Meyer-Olkin Measure of Sampling } \\
\text { Adequacy. }\end{array}$ & 0.844 \\
\hline
\end{tabular}

\begin{tabular}{|l|l|l|}
\hline Bartlett's Test of Sphericity & $\begin{array}{l}\text { Approx. Chi- } \\
\text { Square }\end{array}$ & 2866.242 \\
\cline { 2 - 3 } & Df & 120 \\
\cline { 2 - 3 } & Sig. & .000 \\
\hline Total Variance Explained & $68.803 \%$ \\
\hline
\end{tabular}

Source:Authors'compilation result (2021)

With KMO test result of 0.844 (higher than benchmark of 0.5 ) indicates the proportion of variance in these variables that might be caused by underlying factors, and the EFA is useful with this database. The significant level of Bartlett's test of 0 (lower than the benchmark of 0.05) also confirm this fact that all independent variables are related to the dependent variable, and EFA is the good choice.

Table 3. Results of rotation matrix

\begin{tabular}{|l|l|l|l|l|l|}
\hline \multicolumn{5}{|l|}{ Rotated Component Matrix ${ }^{\mathrm{a}}$} \\
\hline & 1 & 2 & 3 & 4 & 5 \\
\hline & Component & .789 & & & \\
\hline KT1 & & .816 & & & \\
\hline KT4 & & .785 & & & \\
\hline XHH1 & & & .762 & & \\
\hline XHH2 & & & .743 & & \\
\hline XHH3 & & & .716 & & \\
\hline XHH4 & & & .527 & & \\
\hline XHH5 & .743 & & & & \\
\hline XHH6 & .752 & & & & \\
\hline XHH7 & .842 & & & & \\
\hline XHH8 & .778 & & & & \\
\hline SK1 & & & & .767 & \\
\hline SK2 & & & & .798 & \\
\hline SK3 & & & & .682 & \\
\hline CV1 & & & & & .702 \\
\hline CV2 & & & & & .865 \\
\hline
\end{tabular}

Source:Authors' compilation result (2021)

The factor load coefficients are all greater than 0.5 and there is no case of variables uploading both factors at the same time with close coefficients.

However, according to the results of the rotation matrix, the financial socialization factor has been divided into two new subfactors. The first new sub-facfor group includes: XHH1, XHH2, XHH3, XHH4. The second one consists of XHH5, XHH6, XHH7, XHH8. Combined with the theoretical basis and question content of the observed variables belonging to socialization factors, the research team agreed to name the first new group: Financial habits from parents (TQ), the second new group: Financial education from parents (GD).

After extracting EFA factors, from 21 observed variables was reduced to 16 observed variables, then separated into 5 factors and the factors were named as follows:

Table 4: Components of key factors

\begin{tabular}{|l|l|}
\hline Factors & Components \\
\hline Financial knowledge (KT) & KT1, KT2, KT4 \\
\hline $\begin{array}{l}\text { Financial habits from } \\
\text { parents (TQ) }\end{array}$ & $\begin{array}{l}\text { XHH1, XHH2, XHH3, } \\
\text { XHH4 }\end{array}$ \\
\hline Financial education from & XHH5, XHH6, XHH7, \\
\hline
\end{tabular}




\begin{tabular}{|l|l|}
\hline parents (GD) & XHH8 \\
\hline Financial well-being (SK) & SK1, SK2, SK3 \\
\hline Covid 19 pandemic (CV) & CV1, CV2 \\
\hline
\end{tabular}

Source: Authors' consolidation result (2021)

Because the variable socialization has been split into two new variables, hypothesis 4 is splitted into 2 new hypotheses, hypothesis 4.1 and 4.2, as follows:
- H 4.1: "Financial habits from parents have a positive impact (+) on financial management behavior."

- H 4.2: "Financial education from parents has a positive impact (+) on financial management behavior."

\subsection{Results of Regression Analysis and Hypothesis Testing}

We have the results of regression analysis as follows:

Table 5: Regression analysis result on determinants of personal financial management behavior

\begin{tabular}{|l|l|l|l|l|l|}
\hline Model Summary & \\
\hline Model & R & R Square & Adjusted R Square & Std. Error of the Estimate & Durbin-Watson \\
\hline 1 & $0.670^{\text {a }}$ & 0.449 & 0.443 & 0.568639 & 1.930 \\
\hline a. Predictors: (Constant), GT, GD, SK, CV, TQ & & & \\
\hline b. Dependent Variable: H_V & & & \\
\hline
\end{tabular}

Source: Authors' compilation result (2021)

The coefficient $\mathrm{R}$ Square is 0.449 which means the independent variable explains $44.9 \%$ of the variation of the dependent variable.

Table 6: Regression Result

\begin{tabular}{|c|c|c|c|c|c|}
\hline \multicolumn{6}{|l|}{ Coefficients $^{\mathrm{a}}$} \\
\hline \multirow[b]{3}{*}{ Model } & \multirow{2}{*}{\multicolumn{2}{|c|}{$\begin{array}{l}\text { Unstandardized } \\
\text { Coefficients }\end{array}$}} & \multirow{3}{*}{\begin{tabular}{|l}
$\begin{array}{l}\text { Standardized } \\
\text { Coefficients }\end{array}$ \\
Beta
\end{tabular}} & \multirow[b]{3}{*}{$\mathrm{T}$} & \multirow[b]{3}{*}{ Sig. } \\
\hline & & & & & \\
\hline & B & Std. Error & & & \\
\hline \begin{tabular}{|l|l|}
1 & (Constant $)$
\end{tabular} & .995 & .136 & & 7.292 & .000 \\
\hline KT & .016 & .034 & .019 & .468 & .640 \\
\hline SK & .105 & .035 & .124 & 3.052 & .002 \\
\hline $\mathrm{CV}$ & .337 & .032 & .397 & 10.403 & .000 \\
\hline TQ & .208 & .036 & .244 & 5.727 & .000 \\
\hline$\overline{\mathrm{GD}}$ & .109 & .030 & .140 & 3.650 & .000 \\
\hline
\end{tabular}

Source: Authors' compilation result (2021)
The regression model result is rewritten as follows:

$$
\text { H_V }=1+0.337 * \mathrm{CV}+0.109 * \mathrm{GD}+0.208 * \mathrm{TQ}+0.105 * \mathrm{SK}
$$

The significance level of the financial knowledge variable greater than 0.05 ; then Ho is accepted. The meaning is there is no influence between financial knowledge and the personal financial management behavior.

5.5. Comparison the differences among gender. occupation on personal financial management behavior.

Gender : To test gender differences in individual financial management behavior, the research team used T-test analysis with two independent variables. The analytical results from the data obtained are as follows:

Table 7: Analysis of differences in behavior by gender

\begin{tabular}{|l|l|l|l|l|l|l|}
\hline \multicolumn{2}{|c|}{} & Levene's Test for Equality of Variances & \multicolumn{1}{l|}{ t Test for Equality of Means } \\
\cline { 3 - 8 } \multicolumn{2}{|c|}{} & F & Sig & T & Df & Sig.(2-tailed) \\
\hline \multirow{2}{*}{ H_V } & Equal variances assumed & .259 & .611 & .638 & 475 & .524 \\
\cline { 2 - 8 } & Equal variances not assumed & & & .619 & 211.902 & .536 \\
\hline
\end{tabular}

Source: Authors' compilation result (2021)

Levene test for P-value greater than 0.05 proves that the variance between the two groups of male and female is homogeneous. The result of the significance level corresponding to the equal variance assumption is $0.524>0.05$. Therefore, we conclude that there is no gender difference in individual financial management behavior.

Occupation: To test differences in occupational status to behavior, the team used one-way ANOVA analysis. Analysis results from the data obtained:

Table 8: Results of Levene Test

Test of Homogeneity of Variances

\begin{tabular}{|l|l|l|l|l|l|}
\hline \multicolumn{2}{|l|}{} & Levene Statistic & df1 & df2 & Sig. \\
\hline H_V & Based on Mean & 2.204 & 2 & 474 & .112 \\
\hline
\end{tabular}

Source: Authors' compilation result (2021)
Levene test gives $\mathrm{P}$-value greater than 0.05 proving that the variance of groups of values is homogeneous, so we use ANOVA with the following result.

Table 9: Results of analysis of differences by occupation status

\begin{tabular}{|l|l|l|l|l|l|}
\hline & $\begin{array}{l}\text { Sum of } \\
\text { Squares }\end{array}$ & Df & $\begin{array}{l}\text { Mean } \\
\text { Square }\end{array}$ & F & Sig. \\
\hline $\begin{array}{l}\text { Between } \\
\text { Groups }\end{array}$ & 3.751 & 2 & 1.876 & 3.263 & .039 \\
\hline $\begin{array}{l}\text { Within } \\
\text { Groups }\end{array}$ & 272.429 & 474 & .575 & & \\
\hline Total & 276.181 & 476 & & & \\
\hline
\end{tabular}

Source: Authors' compilation result (2021)

Significance level $=.039<.05$ implying that there is a statistical difference in the mean score, people with different occupational status have different financial management behavior. 


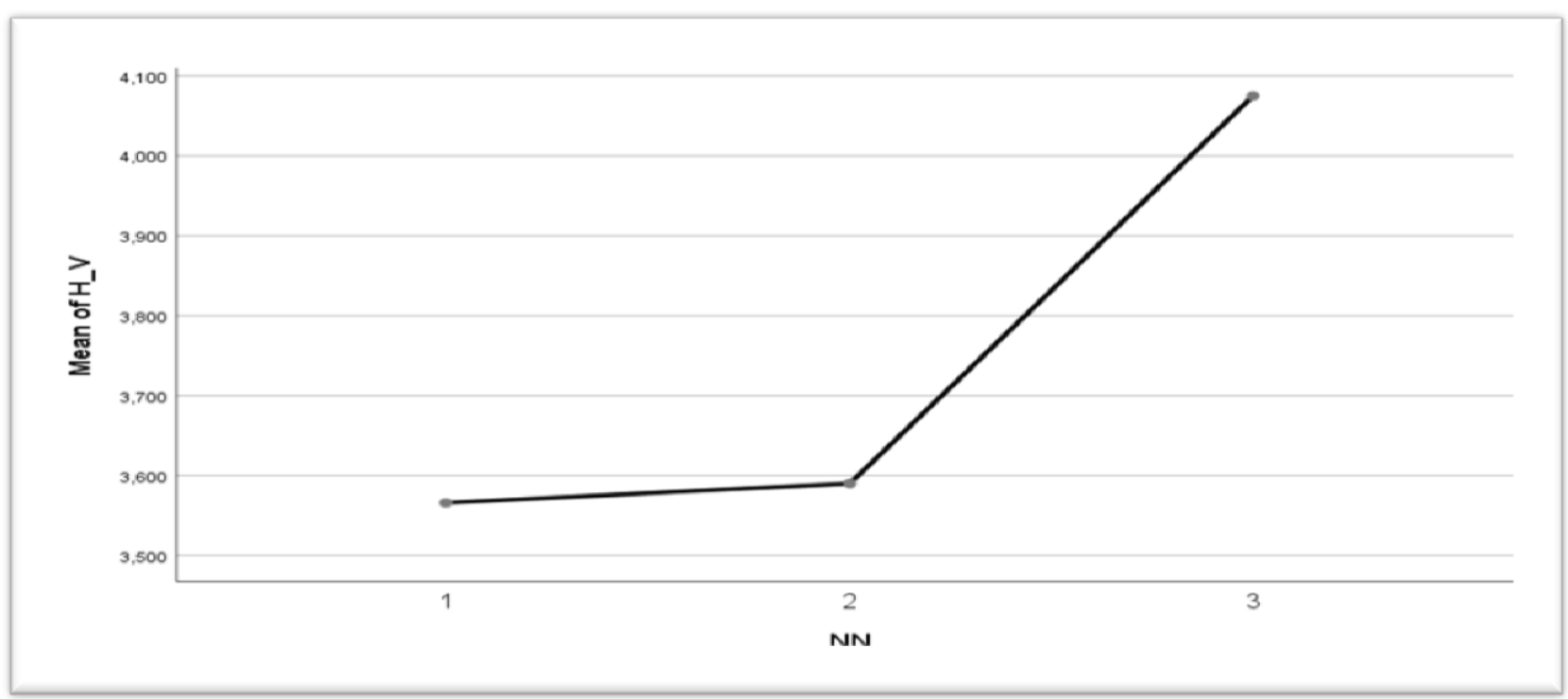

Figure 3: Differences by occupation status

Source: Authors' compilation result (2021)

The increasing Mean value shows that employees manage their personal finances better than students, while unemployees have stricter financial management behavior than employees.

\subsection{Results of hypothesis testing}

From the above analysis, the research team has summarized the results of testing the following hypotheses:

Table 10:The results of testing research hypotheses.

\begin{tabular}{|l|l|l|}
\hline Hypothesis & Expected signal & Actual result \\
\hline H1 & $\begin{array}{l}\text { Financial knowledge has a } \\
\text { positive impact on personal } \\
\text { financial management behavior . }\end{array}$ & Rejected \\
\hline H2 & $\begin{array}{l}\text { Financial attitudes have a } \\
\text { positive impact on personal } \\
\text { financial management behavior }\end{array}$ & \\
\hline H3 & $\begin{array}{l}\text { Financial well-being has a } \\
\text { positive impact on personal } \\
\text { financial management behavior }\end{array}$ & Accept \\
\hline H4.1 & $\begin{array}{l}\text { Financial habits from parents } \\
\text { have a positive impact on } \\
\text { personal financial management } \\
\text { behavior }\end{array}$ & Accept \\
\hline H4.2 & $\begin{array}{l}\text { Financial education from parents } \\
\text { has a positive impact on } \\
\text { personal financial management } \\
\text { behavior }\end{array}$ & \\
\hline H5 & $\begin{array}{l}\text { The Covid-19 pandemic } \\
\text { has positive impact on personal } \\
\text { financial management behavior }\end{array}$ & \\
\hline
\end{tabular}

Source: Authors' compilation result (2021)

In the case of Vietnamese, the main findings about financial management behavior are:

First, Covid 19 pandemic has positive impacts on personal financial management behavior, which confirm more this hypothesis with the empirical study from Vietnam. During COVID-19 pandemic, people tend to be more risk-adverse, paying attention to their personal finance issues.
Second, financial habits and financial education from parents to financial management behavior, which supports these two hypotheses. This come from the specific characteristics of Vietnam culture: First, parents are the main financial sources for the youth, and also the model of financial management for children. Second, as financial management capacity building courses are not much available in Vietnam, people depend on family own 's experiences to build up their financial management behaviors.

Third, there is positive influence of financial well-being to financial management behavior. People who are satisfied with financial well-being tends to have better behaviors.

Fourth, in case of low- income countries as Vietnam, financial knowledge and financial attitude are considered to have little impact on financial management behavior, which is suitable with a previous study of Herdjiono \& Damanik (2016).

Fifth, whereas occupational status has significant to financial management behavior, gender has no influence on financial management behavior. This can be seen in the way that those people have occupation tends to complete financial habits constantly such as managing budget.

\section{Recommendations and Limitation}

\section{Recommendations}

Based on the results of the analysis of the factors affecting the behavior management of individuals, groups of authors propose a few recommendations to impact positively on the behavior management's personal Vietnam in the context of service Covid 19.

- For individuals: It is expected that individuals are able to develop more in managing their finances by following positive financial behaviors of their parents. Moreover, people also ought to participate more in seminars on financial literacy held by government institutions.

- For the government: This research can be used as one of the references to express and provide socialization through seminars in improving management, improving good financial attitudes, and improving students' financial literacy and providing curricula for higher education courses with good expectations from the 
community especially students will be very important to get life prosperity in the future with one of the best ways to manage finances well.

- For commercial banks: The results of this study show that the external environment, namely the Covid 19 pandemic occurred, made the financial management behavior of individuals stricter because they had to be cautious in your own spending in particular and your economic management in general. Therefore, this is also an opportunity for commercial banks to strengthen their role and presence. Commercial banks need to support individual customers with special interest rate discounts and incentives for loyal customers with good credit scores. To bring financial services to more citizens, commercial banks should strengthen cooperation with financial technology companies (fintech) in providing high-tech banking services.

- For the State Bank of Vietnam - SBV (Central Bank): SBV should develop the enabling environment for financial service providers to implement the responsible and responsive approaches to clients. SBV also should design and develop relevant financial eduction campaigns to increase financial literacy level of people.

\section{Limitations of the research}

This research as some limitations in: (i) selection of survey sample not cover all age levels, but focusing more on young people; (ii) not yet include all macro factors in PESTLE model in the determinants of personal financial management behaviors; (iii) the scenario of Covid-19 pandemic are not totally updated to now.

\section{Conflicts of interest}

Authors declare that there is no conflict of interest regarding the publication of this paper.

\section{Funding statement}

This research did not receive any specific grant from funding angencies in the public, commercial, or not-for-profit sectors.

\section{References}

Foreign references

[1] Amanah, E., Rahardian, D., \& Iradianty, A. (2016), Pengaruh Financial Knowledge, Financial Attitude dan External Locus Of Control Terhadap Personal Financial Management Behavior Pada Mahasiswa S1 Universitas Telkom. E-Proceeding of Management, 3(2), 1228-1235.

[2] Ameliawati M. \& Setiyani R. (2018), The influence of Financial Attitude, Financial Socialization, and Financial Experience to Financial Management Behaviour with Literacy as the Mediation Variable, KnE Social Sciences, vol .3, no.10, pp.811, 2018.

[3] Arifin, A. (2017), The Influence of Financial Knowledge, Control and Income on Individual Financial Behavior, European Research Studies Journal, Volume XX, Issue 3A, 2017, pp. 635648.
[4] Borden, L. M., Lee, S. A., Serido, J. \& Collins, D. (2008), Changing college students' financial knowledge, attitudes, behavior through seminar participation, Journal of Family and Economic Issues, 29(1): 23-40.

[5] CEIC (2021), Vietnam Retail Sales Growth, https://www.ceicdata.com/en/indicator/vietnam/retail-sales-growth

[6] Experian (2020), Experian Survey: How Is The Pandemic Affecting Personal Finances? https://www.experian.com/blogs/askexperian/research/survey-how-is-the-pandemic-affecting-personalfinances/

[7] Gflec.org. 2021. [online] Available at: <https://gflec.org/wpcontent/uploads/2015/11/3313-Finlit_Report_FINAL5.11.16.pdf?x49160>

[8] Global Risks Report 2021. 2021. Global Risks 2021: Fractured Future. [online] Available at: <http://reports.weforum.org/globalrisks-report-2021/global-risks-2021-fractured-future/>.

[9] Herdjiono, I. \& Damanik, A. (2016), Pengaruh Financial Attitude, Financial Knowledge, Parental Income Terhadap Financial Management Behavior, Journal Manajemen Teori Dan Terapan, 9(3), 226-241.

[10] Hilgert, M. A., Hogarth, J. M. \& Beverly, S. G. (2003), Household financial management: The connection between knowledge and behavior, Federal Reserve Bulletin, 89, 309-322.

[11] Ida I. \& Dwinta C. Y. (2010), The influence of locus of control, financial knowledge and income to financial management behavior, Journal of Business and Accounting, 12(3), 131-144.

[12] Joo, H. \& Grable, J. E. (2004), An exploratory framework of the determinants of financial satisfaction, Journal of Family and Economic Issues, 25, 25-50. doi: 10.1023/B:JEEI.0000016722.37994.9f

[13] Joo, H. (2008). Personal financial wellness, In J. J. Xiao (Ed.), Handbook of consumer finance research (pp. 21-33). New York: Springer.

[14] Jorgensen, B. L., Rappleyea, D. L., Schweichler, J.T., Fang, X. \& Moran, M.E. (2017), The financial behavior of emerging adults: A family financial socialization approach, Journal of Family and Economic Issues, 38(1), 57-69.

[15] Kholilah, N. A. \& Iramani, R. (2013). Studi Financial Management Behavior Pada Masyarakat Surabaya, Journal of Business and Banking, 3(1), 69-80.

[16] Kim, J., Garman, E. T. \& Sorhaindo, B. (2003), Relationships among credit counseling clients' financial well-being, financial behaviors, financial stressor events, and health, Financial Counseling and Planning, 14, 75-87.

[17] Mien, N. T. N. \& Thao, T. P. (2015), Factors Affecting Personal Financial Management Behaviors: Evidence from Vietnam, Proceedings of the Second Asia-Pacific Conference on Global Business, Economics, Finance and Social Sciences ISBN: 978-1-63415-833-6, 10-12. 
[18] N. Beatty, S. E., \& Capella, M. L. (2006). Teenagers' use of alternative shopping channels: A consumer socialization perspective. Journal of Retailing, 82 (June), 137-153.

[19] OECD (2020), OECD/INFE 2020 International Survey of Adult Financial Literacy

[20] Parrotta, J., \& Johnson, P. (1998). The Impact Of Financial Attitudes And Knowledge On Financial Management And Satisfaction Of Recently Married Individuals Journal of Financial Counseling and Planning, 9(2), 59-75.

[21] Sass, D. A., \& Schmitt, T. A, “A comparative investigation of rotation criteria within exploratory factor analysis", Multivariate Behavioral Research", 45(1). 73-103. 2010

[22] Sina, P. G., \& Noya, A. (2012). Pengaruh Kecerdasan Spiritual Terhadap. Jurnal Manajemen, 11(2), 171-188.

[23] Shim, S., Barber, B. L., Card, N. A., Xiao, J. J., \& Serido, J. (2010), Financial socialization of first-year college students: The roles of parents, work, and education, Journal of Youth and Adolescence, 39, 1457-1470. doi: 10.1007/s10964-009-9432-x.

[24] Shim, S., Xiao, J. J., Barber, B., \& Lyons, A. (2009), Pathways to life success: A conceptual model of financial wellbeing for young adults, Journal of Applied Developmental Psychology, 30, 708-723.

[25] Woodyard, A. \& Robb, C. (2012), Financial Knowledge and the Gender Gap, Journal of Financial Al Therapy, Vol.3, Issue 1, 2012

[26] Xiao, J. J. \& Dew, J. (2011), The financial management behavior scale: development and validation, Journal of Financial Counseling and Planning, 22(1): 49-53.
[27] Xiao, J. J., Tang, C. \& Shim, S. (2009), Acting for happiness: Financial behavior and life satisfaction of college students, Social Indicators Research, 92, 53-68/

[28] Yap, C. J. R., Komalasari, F. \& Hadiansah, I. (2016)., The Effect of Financial Literacy and Attitude on Financial Management Behavior and Satisfaction, International Journal of Administrative Science \& Organization, 23(3) 140-146.

Vietnamese references

[1] Baodautu. 2021. Tín dụng cá nhân sụt giảm, lợi nhuận ngân hàng năm 2020 dự kiến chỉ tăng 4,9\%. [online] Available at: $<$ https://baodautu.vn/tin-dung-ca-nhan-sut-giam-loi-nhuan-nganhang-nam-2020-du-kien-chi-tang-49-d128759.html>

[2] Báo Nhân Dân. 2021. Chính sách vượt qua tác động của dịch Covid-19, nhằm phục hồi và phát triển kinh tế. [online] Available at: <https://nhandan.com.vn/tin-tuc-kinh-te/chinh-sach-vuot-quatac-dong-cua-dich-covid-19-nham-phuc-hoi-va-phat-trien-kinh-te-620553/>

[3] Cafef.vn. 2021. Hành vi tiêu dùng: Đàn ông ít lo lắng hơn nhưng lại mua sắm online nhiều hơn phụ nữ trong dịch Covid-19. [online] Available at: <https://cafef.vn/hanh-vi-tieu-dung-dan-ongit-lo-lang-hon-nhung-lai-mua-sam-online-nhieu-hon-phu-nu-trongdich-covid-19-2020041718081019.chn>

[4] https://phuongnam.reatimes.vn. 2021. Tín dụng năm 2020 tăng trưởng ở mức nào? [online] Available at: $<$ https://phuongnam.reatimes.vn/tin-dung-nam-2020-tang-truongo-muc-nao-1606384715770.html> 